\title{
Zachowania zdrowotne i umiejętności w zakresie profilaktyki możliwych powikłań u pacjentów z nadciśnieniem tętniczym
}

\section{Health behaviour and skils in prevention of complications In patiens with arterial hypertension}

\author{
ANNA PIOTROWSKA ${ }^{1,2}$, AGNIESZKA PIERNIKOWSKA ${ }^{1,3}$, \\ ANNA MIZIEWICZ4 \\ ${ }^{1}$ Instytut Nauk o Zdrowiu, Państwowa Uczelnia Zawodowa we Włocławku \\ 2 Wojewódzki Szpital Specjalistyczny we Włocławku im. bł. ks. J. Popiełuszki, Oddział \\ Dziecięcy \\ 3 Wojewódzki Szpital Specjalistyczny we Włocławku im. bł. ks. J. Popiełuszki, Oddział \\ Chorób Wewnętrznych i Nefrologii \\ ${ }^{4}$ Instytut Gruźlicy i Chorób Płuc w Warszawie
}

DOI: http://dx.doi.org/10.21784/IwP.2019.014

ISSN: 2451-1846

\section{Streszczenie:}

Wstęp. Zachowania zdrowotne to wszelkie zachowania lub ich brak, które mają związek ze zdrowiem i samopoczuciem człowieka. Zachowania zdrowotne można podzielić na sprzyjające zdrowiu oraz antyzdrowotne. Zachowania prozdrowotne służą wspieraniu zdrowia, zapobieganiu chorobie oraz wspomaganiu powrotu do zdrowia. Zachowania antyzdrowotne przyczyniają się do powstania zaburzeń stanu zdrowia.

Cel. Celem pracy jest zbadanie poziomu umiejętności pacjentów z nadciśnieniem tętniczym w zakresie profilaktyki możliwych powikłań.

Materiał i metody. Materiał badawczy uzyskano za pomocą sondażu diagnostycznego. Natomiast jako narzędzie wykorzystano kwestionariusz ankiety składający się z metryczki oraz części głównej badającej poziom umiejętności chorych $\mathrm{z}$ nadciśnieniem tętniczym. Kwestionariusz ankiety zawierał 20 pytań i były to pytania w formie zamkniętej. Badania 
przeprowadzono w okresie od maja do czerwca 2017 roku na Oddziale Kardiologii Specjalistycznego Szpitala Wojewódzkiego w Ciechanowie. Uczestniczyło w nim 100 pacjentów Oddziału Kardiologii, przy czym każdy uczestnik był osobą pełnoletnią. Respondenci otrzymali informacje dotyczące zasad wypełnienia kwestionariusza ankiety, a także zapewnienie o anonimowości zebranych danych.

Wyniki. W prowadzonych badaniach nie wykazano korelacji pomiędzy wykształceniem, miejscem zamieszkania, aktywnością zawodową i czasem trwania choroby ankietowanych a ich poziomem umiejętności w zakresie profilaktyki powikłań.

Wnioski. Mobilizacja pacjenta do samokontroli i obserwacji niepokojących objawów tworzy spójną całość w procesie terapeutycznym. Włączenie chorego do procesu leczniczego poprzez mobilizowanie do samokontroli pacjenta $\mathrm{w}$ domu a także przygotowanie oraz poinformowanie chorego o prawidłowości w wykonywaniu poszczególnych czynności podczas samodzielnych pomiarów ma ogromne znaczenie w leczeniu nadciśnienia tętniczego krwi.

Słowa kluczowe: nadciśnienie tętnicze, powikłania, zachowania zdrowotne

\begin{abstract}
:
Introduction. Health behaviour is the acticity undertaken (or not) by people for the purpose of maintaining their health and well-being. Health behaviour can be divided into behaviour fostering health and unhealthy behaviour. Healthy attitude enhances health, prevents illness and fosters recovery. Unhealthy attitude contributes to health disorders.
\end{abstract}

Aim. The aim of this study is to asses the level of skills in prevention of complications in patients with arterial hypertension.

Material and method. The study used a diagnostic survey. A questionnaire consisting of metrics and main part devoted to assesment of patients skills level was used a research tool. The questionnaire included 20 closed questions. The study was carried out in the period from May to June 2018 in department of cardiology in Specialist Hospital in Ciechanów. The study covered 100 patients and each of them was a person of age. Respondents were informed about rules on filling in the questionnaire and the fact that data were rendered anonymous for statistical purposes. 
Results. The study showed no connection among education, place of residence, professional activity and disease duration of respondents and their level or skills in prevention of complications.

Conclusions. Mobilising patients to self-control and observe disturbing symptoms contributes to successful treatment process. Including the sufferers in the treatment process and mobilising them to self-control together with preparing and instructing them on the right measurements of blood pressure is of signifact importance in arterial hypertension treatment.

Keywords: arterial hypertension, complications, health behavior

\section{Wstęp}

Liczba chorych na nadciśnienie tętnicze wzrasta wraz z zaawansowaniem wieku. $U$ osób powyżej 55 roku życia prawdopodobieństwo wystąpienia choroby sięga nawet $90 \%$. W populacji mężczyzn nadciśnienie tętnicze nieznacznie częściej występuje przed ukończeniem 60 roku życia, w grupie kobiet z kolei po 60 roku życia [1]. Rozwój choroby i jej powikłań w obrębie układu sercowo-naczyniowego uwarunkowany jest czynnikami ryzyka, wynikającymi $\mathrm{z}$ negatywnych zachowań $\mathrm{w}$ ramach stylu życia [2]. Konsekwencje nieleczonego nadciśnienia tętniczego to m.in. udar mózgu, zawał mięśnia sercowego, niewydolność nerek. Z biegiem czasu może dojść do przerostu lewej komory serca a także rozwarstwiania aorty. Powikłania nadciśnienia tętniczego przedstawia Tabela nr 1. 
Tab. 1. Powikłania nieleczonego i źle leczonego nadciśnienia tętniczego [3].

\begin{tabular}{|c|c|c|}
\hline Powikłania & $\begin{array}{l}\text { Objawy, częstość } \\
\text { występowania }\end{array}$ & Mechanizm \\
\hline $\begin{array}{l}\text { Choroba } \\
\text { niedokrwienna } \\
\text { serca }\end{array}$ & $\begin{array}{l}\text { - Bóle zamostkowe } \\
\text { (dławica piersiowa) } \\
\text { - Zawał } \\
\text { - Nagła śmierć } \\
\text { wieńcowa } \\
\text { (występuje istotnie } \\
\text { częściej niż u osób } \\
\text { zdrowych) }\end{array}$ & $\begin{array}{l}\text { - Zmniejszenie rezerwy } \\
\text { wieńcowej } \\
\text { - Przyśpieszenie miażdżycy w } \\
\text { naczyniach wieńcowych } \\
\text { - Przerost mięśniówki gładkiej } \\
\text { naczyń wieńcowych }\end{array}$ \\
\hline $\begin{array}{l}\text { Przerost lewej } \\
\text { komory }\end{array}$ & $\begin{array}{l}\text { - U } 20 \text { - 50\% } \\
\text { (ryzyko rośnie z } \\
\text { czasem trwania } \\
\text { choroby, } \\
\text { wysokością } \\
\text { ciśnienia i wiekiem) }\end{array}$ & $\begin{array}{l}\text { - Pogrubienie ścian lewej komory } \\
\text { w wyniku przerostu komórek } \\
\text { mięśniowych spowodowanego } \\
\text { zwiększonym obciążeniem. } \\
\text { Konsekwencją jest wzrost } \\
\text { zapotrzebowania na tlen i } \\
\text { zmniejszenie się rezerwy } \\
\text { wieńcowej. Dochodzi do } \\
\text { drobnych, rozsianych ognisk } \\
\text { martwicy i włóknienia. }\end{array}$ \\
\hline $\begin{array}{l}\text { Zastoinowa } \\
\text { niewydolność } \\
\text { krążenia }\end{array}$ & $\begin{array}{l}-2-5 \% \text { wszystkich } \\
\text { przyjęć do szpitali, } \\
\text { najczęstszą jej } \\
\text { przyczyną jest } \\
\text { nadciśnienie } \\
\text { tętnicze }\end{array}$ & $\begin{array}{l}\text { - Przerost lewej komory serca } \\
\text { - Zmniejszenie kurczliwości serca }\end{array}$ \\
\hline $\begin{array}{l}\text { Powikłania } \\
\text { mózgowe }\end{array}$ & $\begin{array}{l}\text { - Udar } \\
\text { niedokrwienny } \\
\text { mózgu } \\
\text { - Przejściowe ataki }\end{array}$ & $\begin{array}{l}\text { - Zaburzenia autoregulacji } \\
\text { krążenia mózgowego } \\
\text { - Przyśpieszenie tworzenia } \\
\text { blaszek miażdżycowych }\end{array}$ \\
\hline
\end{tabular}




\begin{tabular}{|l|l|l|}
\hline & $\begin{array}{l}\text { niedokrwienne } \\
\text { - Encefalopatia } \\
\text { nadciśnieniowa } \\
\text { (otępienie) }\end{array}$ & - Mikrotętniaki \\
- Krwawienie śródmózgowe \\
\hline $\begin{array}{l}\text { Retinopatia } \\
\text { nadciśnieniowa }\end{array}$ & $\begin{array}{l}\text { - Zaburzenia } \\
\text { widzenia } \\
\text { - Przemijająca } \\
\text { jednostronna } \\
\text { ślepota } \\
\text { - Utrata wzroku (w } \\
\text { skrajnych } \\
\text { przypadkach, } \\
\text { zwłaszcza u ludzi } \\
\text { starszych) }\end{array}$ & $\begin{array}{l}\text { - Wzrost napięcia ścian naczyń } \\
\text { - Urak autoregulacji ścian naczyń } \\
\text { - Uszkodzenenie siatkówki naczyniówki }\end{array}$ \\
\hline $\begin{array}{l}\text { Powikłania } \\
\text { nerkowe }\end{array}$ & $\begin{array}{l}\text { - Zakrzep tętnicy siatkówki } \\
\text { - Białkomocz } \\
\text { - Przewlekła } \\
\text { niewydolność nerek } \\
\text { - Mocznica }\end{array}$ & $\begin{array}{l}\text { - Pogrubienie ścian tętnic } \\
\text { nerkowych (zwężenie ich światła) } \\
\text { - Niedokrwienie kłębuszków }\end{array}$ \\
\hline
\end{tabular}

Metody leczenia nadciśnienia tętniczego obejmują farmakoterapię a także zmianę stylu życia w dążeniu do normalizacji wartości ciśnienia tętniczego krwi [4]. Modyfikacja czynników ryzyka choroby, takich jak: palenie tytoniu, stres, zaburzenia lipidowe czy otyłość sprzyja redukcji ryzyka sercowo-naczyniowego [5]. Strategię terapii ustala się indywidualnie dla każdego pacjenta. Konieczne jest ustalenie podłoża rozwoju choroby, obecności chorób współistniejących oraz analiza możliwych powikłań sercowonaczyniowych[6].

Leczenie hipotensyjne stosuje się $\mathrm{w}$ nadciśnieniu o charakterze wtórnym, gdzie występuje uchwytna przyczyna choroby i jest ona potencjalnie możliwa do usunięcia[7]. 
Bardzo często dobranie odpowiedniego leczenia dla danego chorego wymaga wiele czasu i zaangażowania, gdyż reakcja każdego z pacjentów na zastosowane leczenie może się znacznie różnić. Niekiedy konieczne jest zastosowanie nawet kilku leków hipotensyjnych. W terapii nadciśnienia tętniczego wykorzystywane są leki moczopędne (diuretyki), które wykazują dobrą tolerancję i skuteczność działania. Zmniejszają ilość sodu oraz wody w świetle naczyń, co powoduje ich rozszerzenie. W stosowaniu leków moczopędnych bardzo ważne jest uzupełnianie potasu w organizmie, ponieważ jest on wydalany wraz z moczem, co może prowadzić do jego niedoborów[5].

Kolejną grupą leków obniżających ciśnienie tętnicze krwi są leki blokujące receptory beta układu współczulnego czyli beta-blokery. Działają one w mechanizmie blokowania receptorów znajdujących się w mięśniu serca a także w ścianach naczyń, w wyniku czego następuje osłabienie siły skurczu serca. Zmniejsza się wówczas zapotrzebowanie mięśnia sercowego na tlen. Beta-blokery często stosuje się $\mathrm{u}$ chorych $\mathrm{z}$ chorobą wieńcową, po zawale mięśnia sercowego czy przy zaburzeniach rytmu serca[8].

Antagoniści wapnia hamują przenikanie jonów wapnia do ścian komórek, przez co rozszerzają naczynia krwionośne, a co za tym idzie obniżają ciśnienie krwi. Z kolei inhibitory konwertazy angiotensyny działają poprzez zahamowanie angiotensyny II, która jest hormonem podnoszącym ciśnienie krwi. Leki $\mathrm{z}$ tej grupy zwiększają wydzielanie bradykininy, tlenku azotu i prostacykliny, które są substancjami powodującymi obniżenie ciśnienia. Leki te wykazują wybiórcze zablokowanie receptora, przez który wywiera działanie angiotensyna II i są nazywane lekami blokującymi receptory angiotensyny II.

Alfa-blokery $\mathrm{z}$ kolei blokują receptory alfa układu współczulnego, poprzez swoje działanie rozszerzają drobne tętniczki, wykazując działanie hipotensyjne. Ponadto leki z tej grupy wpływają pozytywnie na przemianę tłuszczową i węglowodanową. 
Oprócz monoterapii czyli pojedynczych leków, w terapii nadciśnienia tętniczego stosuje się leczenie skojarzone czyli preparaty złożone, które zawierają więcej niż jedną substancję obniżającą ciśnienie. Wykazują one najczęściej długotrwałe działanie zatem mogą być podawane $w$ jednorazowej dawce dziennej[9].

Dla skuteczności zastosowanego leczenia bardzo ważnym jest, aby stosowane leki były przyjmowane regularnie a chorzy nie przerywali ich stosowania po ustabilizowaniu wartości ciśnienia tętniczego. Leczenie farmakologiczne nadciśnienia tętniczego trwa najczęściej całe życie chorego[10].

W diagnostyce choroby i doborze leków w ramach farmakoterapii niezbędna jest analiza wyników pomiarów ciśnienia tętniczego krwi podczas wizyty pacjenta $\mathrm{w}$ gabinecie lekarskim lub poprzez dokonanie całodobowego ambulatoryjnego pomiaru ciśnienia tętniczego. Kontrolujemy w ten sposób wartość ciśnienia tętniczego co 15-20 minut w ciągu dnia oraz co 30 minut w nocy [11]. Wyniki pozwalają na weryfikację dobowej zmienności ciśnienia tętniczego, rozpoznanie nadciśnienia białego fartucha czy nadciśnienia maskowanego[2].

\section{Materiał i metody}

Badaniem objęto 100 dorosłych pacjentów w Oddziale Kardiologii Specjalistycznego Szpitala Wojewódzkiego w Ciechanowie.

\section{Wyniki}

W badaniu uczestniczyło 52\% kobiet i 48\% mężczyzn. Informacje dotyczące wykształcenia respondentów zaprezentowano w Tabeli nr 2. 
Tab. 2. Wykształcenie badanych.

\begin{tabular}{|l|l|l|}
\hline Wykształcenie & $\mathbf{N}$ & $\mathbf{\%}$ \\
\hline podstawowe & 11 & 11 \\
\hline zawodowe & 37 & 37 \\
\hline średnie & 34 & 34 \\
\hline wyższe & 18 & 18 \\
\hline Ogółem & 100 & 100 \\
\hline
\end{tabular}

Źródło: wyniki badań własnych

Najliczniejsza grupa respondentów posiadała wykształcenie zawodowe (37\%), wykształcenie średnie dotyczyło 34\% osób. Z kolei $18 \%$ respondentów legitymowało się wykształceniem wyższym a $11 \%$ badanych wykształceniem podstawowym.

Tab. 3. Miejsce zamieszkania badanych.

\begin{tabular}{|l|l|l|}
\hline Miejsce zamieszkania & $\mathbf{N}$ & $\mathbf{\%}$ \\
\hline miasto & 40 & 40 \\
\hline wieś & 60 & 60 \\
\hline Ogółem & 100 & 100 \\
\hline
\end{tabular}

Źródło: wyniki badań własnych

Jak wynika z danych zawartych w Tabeli 3 większość badanych (60\%) mieszka na wsi a 40\% osób to mieszkańcy miasta. 
Tab. 4. Aktywność zawodowa badanych.

\begin{tabular}{|l|l|l|}
\hline Aktywność zawodowa & $\mathbf{N}$ & \% \\
\hline pracujący & 64 & 64 \\
\hline nie pracujący & 36 & 36 \\
\hline Ogółem & 100 & 100 \\
\hline
\end{tabular}

Źródło: wyniki badań własnych

Większość badanych (64\%) jest czynnych zawodowo a 36\% respondentów nie pracuje.

Zdecydowana większość respondentów (53\%) wykonuje pomiary ciśnienia tętniczego krwi tylko wtedy, gdy źle się czuje. Codzienne badanie wskazało tylko 19\% chorych. Wyniki pomiarów zapisuje w książeczce kontroli ciśnienia tętniczego krwi tylko 32\% osób a $68 \%$ nie zadeklarowało takiego działania.

Tab. 5. Przyjmowanie leków hipotensyjnych przez badanych.

\begin{tabular}{|l|l|l|}
\hline $\begin{array}{l}\text { Jak często przyjmuje } \\
\text { Pani/Pan leki obniżające } \\
\text { nadciśnienie tętnicze? }\end{array}$ & $\mathbf{N}$ & $\mathbf{\%}$ \\
\hline przyjmuję regularnie & 67 & 67 \\
\hline $\begin{array}{l}\text { przyjmuję tylko gdy mam } \\
\text { wysokie ciśnienie tętnicze }\end{array}$ & 33 & 33 \\
\hline Ogółem & 100 & 100 \\
\hline
\end{tabular}

Źródło: wyniki badań własnych

Jak wynika z Tabeli 5 zdecydowana większość badanych (67\%) deklaruje regularne przyjmowanie leki hipotensyjnych. Sięga po leki 
tylko wtedy, gdy występują wysokie wartości ciśnienia tętniczego krwi $33 \%$ respondentów.

Tab. 6. Zgłaszanie się na wizyty kontrolne przez badanych.

\begin{tabular}{|l|l|l|}
\hline $\begin{array}{l}\text { Czy uczęszcza } \\
\text { Pani/Pan na wizyty } \\
\text { kontrolne do lekarza? }\end{array}$ & $\mathbf{N}$ & $\mathbf{\%}$ \\
\hline TAK & 46 & 46 \\
\hline NIE & 54 & 54 \\
\hline Ogółem & 100 & 100 \\
\hline
\end{tabular}

Źródło: wyniki badań własnych

Kontrolne wizyty u lekarze deklaruje $54 \%$ badanach. Nie podejmuje takiego działania $46 \%$ chorych.

Tab. 7. Palenie papierosów przez badanych.

\begin{tabular}{|l|l|l|}
\hline $\begin{array}{l}\text { Czy pali Pani/Pan } \\
\text { papierosy? }\end{array}$ & $\mathbf{N}$ & \% \\
\hline TAK & 67 & 67 \\
\hline NIE & 33 & 33 \\
\hline Ogółem & 100 & 100 \\
\hline
\end{tabular}

Źródło: wyniki badań własnych

Pali papierosy $67 \%$ chorych. Nie sięga po tytoń $33 \%$ pacjentów. 
Tab. 8. Ilość wypalanych papierosów przez badanych.

\begin{tabular}{|l|l|l|}
\hline $\begin{array}{l}\text { Ile papierosów dziennie } \\
\text { Pani Pan wypala? }\end{array}$ & $\mathbf{N}$ & \% \\
\hline kilka sztuk & 29 & 29 \\
\hline 1 paczkę dziennie & 20 & 20 \\
\hline powyżej 1 paczki & 18 & 18 \\
\hline nie palę & 33 & 33 \\
\hline Ogółem & 100 & 100 \\
\hline
\end{tabular}

Źródło: wyniki badań własnych

Większość badanych (67\%) przyznaje, że pali papierosy w różnej ilości w ciągu dnia: 29\% wypala kilka sztuk, 20\% osób 1 paczkę dziennie a $18 \%$ chorych pali powyżej jednej paczki na dobę. Z kolei 33\% ankietowanych nie sięga po tytoń.

Tab.9. Poziom codziennej aktywności fizycznej badanych.

\begin{tabular}{|l|l|l|}
\hline $\begin{array}{l}\text { Czy Pani/Pana } \\
\text { codzienna aktywność } \\
\text { fizyczna jest: }\end{array}$ & $\mathbf{N}$ & $\%$ \\
\hline duża & 8 & 8 \\
\hline średnia & 72 & 72 \\
\hline mała & 20 & 20 \\
\hline Ogółem & 100 & 100 \\
\hline
\end{tabular}

Źródło: wyniki badań własnych

Większość badanych (72\%) oceniło swoją codzienną aktywność fizyczną jako średnią. Natomiast $20 \%$ chorych określiło 
ją jako małą. Tylko 8\% osób oceniło swoją aktywność fizyczną jako dużą.

Tab.10. Formy aktywności fizycznej badanych.

\begin{tabular}{|l|l|l|}
\hline $\begin{array}{l}\text { Jakie formy } \\
\text { aktywności fizycznej } \\
\text { Pani/Pan realizuje? }\end{array}$ & $\mathbf{N}$ & $\mathbf{\%}$ \\
\hline spacery & 40 & 40 \\
\hline bieganie & 13 & 13 \\
\hline jazda na rowerze & 44 & 44 \\
\hline pływanie & 3 & 3 \\
\hline Ogółem & 100 & 100 \\
\hline
\end{tabular}

Źródło: wyniki badań własnych

Wśród form aktywności podejmowanych przez pacjentów można wymienić: spacery, bieganie, jazdę na rowerze czy pływanie. Najwięcej respondentów w ramach codziennej aktywności fizycznej spaceruje (40\%), bądź jeździ na rowerze (44\%); 13\% osób biega a tylko $3 \%$ pływa.

Tab. 11. Sytuacje stresowe w życiu badanych.

\begin{tabular}{|l|l|l|}
\hline $\begin{array}{l}\text { Czy w Pani/Pana } \\
\text { codziennym życiu często } \\
\text { występują sytuacje } \\
\text { stresowe? }\end{array}$ & $\mathbf{N}$ & $\mathbf{\%}$ \\
\hline często & 29 & 29 \\
\hline czasami & 64 & 64 \\
\hline nie występują & 7 & 7 \\
\hline
\end{tabular}




\begin{tabular}{|l|l|l|}
\hline Ogółem & 100 & 100 \\
\hline
\end{tabular}

Źródło: wyniki badań własnych

Zdecydowana większość badanych (64\%) podała, że sytuacje stresujące dotyczą ich czasami lub często (29\%). Nie doświadcza takich emocji tylko $7 \%$ chorych.

Tab. 12. Radzenie sobie ze stresem przez badanych.

\begin{tabular}{|l|l|l|}
\hline $\begin{array}{l}\text { Czy potrafi Pani / Pan } \\
\text { radzić sobie w } \\
\text { sytuacjach stresowych? }\end{array}$ & N & \% \\
\hline dobrze & 33 & 33 \\
\hline średnio & 45 & 45 \\
\hline słabo & 16 & 16 \\
\hline nie radzę sobie & 6 & 6 \\
\hline Ogółem & 100 & 100 \\
\hline
\end{tabular}

Źródło: wyniki badań własnych

Średnie radzenie sobie ze stresem wskazało $45 \%$ chorych a 33\% pacjentów podało, że radzi sobie z tym dobrze. Trudności w tym zakresie podało $16 \%$ badanych. Natomiast $6 \%$ ankietowanych nie radzi sobie z takimi sytuacjami.

\section{Dyskusja}

Nadciśnienie tętnicze jest przyczyną 6\% zgonów na całym świecie. Potwierdzają wysoki odsetek zgonów z tego powodu także polskie badania (np. NATPOL - 2002; WOBASZ, które odbyły się wlatach 2002 - 2007). Badania te potwierdziły, że najczęstszymi skutkami nadciśnienia tętniczego są: udary mózgu, zawały serca, choroby nerek[12]. 
Czynniki ryzyka nadciśnienia tętniczego dzielą się na modyfikowalne i niemodyfikowalne. Do pierwszych zaliczamy między innymi dietę, otyłość, nadmierne spożycie alkoholu, podwyższone stężenie cholesterolu LDL, zbyt niskie stężenie cholesterolu HDL, duże stężenie trójglicerydów, małą aktywność fizyczną czy stres. Wiek, obciążający wywiad rodzinny a także płeć męska to czynniki niemodyfikowalne [1].

W prezentowanych badaniach skupiono się na wybranych umiejętnościach osób chorujących na nadciśnienie tętnicze. Większość respondentów deklaruje posiadanie własnego aparatu do pomiaru do pomiaru ciśnienia tętniczego, znajomość techniki powyższego badania, regularne przyjmowanie leków hipotensyjnych, codzienną aktywność fizyczną na średnim poziomie. Niemniej jednak większość chorych pali papierosy, średnio radzi sobie w sytuacjach stresowych .

W prowadzonych badaniach nie wykazano korelacji pomiędzy wykształceniem, miejscem zamieszkania, aktywnością zawodową ankietowanych a ich poziomem umiejętności w zakresie profilaktyki powikłań nadciśnienia tętniczego.

\section{Wnioski}

Mobilizacja pacjenta do samokontroli i obserwacji niepokojących objawów tworzy spójną całość w procesie terapeutycznym. Włączenie chorego do procesu leczenia poprzez mobilizowanie do samokontroli $\mathrm{w}$ domu ma ogromne znaczenie w leczeniu nadciśnienia tętniczego krwi. Konieczne jest prowadzenie działań prewencyjnych, mających na celu uświadomienie społeczeństwu, jak przeciwdziałać chorobie, jakie są konsekwencje nadciśnienia tętniczego i do jakich powikłań mogą doprowadzić.

\section{Zalecenia dla praktyki pielęgniarskiej}

Pacjent przygotowany do samoopieki w przebiegu choroby przewlekłej świadomie uczestniczy $\mathrm{w}$ procesie terapii. Zadaniem 
pielęgniarki jest przygotowanie chorego do przejęcia odpowiedzialności za własne zdrowie.

\section{Bibliografia/Bibliography:}

1. Kawecka - Jaszcz K., Urbańska - Pośnik A., Jankowski P. Rozpowszechnienie nadciśnienia tętniczego $\mathrm{w}$ zależności od płci $\mathrm{w}$ świetle badań epidemiologicznych w Polsce. Nadciśnienie tętnicze 2007;(11):5.

2. Biała B., Cicha M. Nadciśnienie tętnicze. Magazyn pielęgniarki i położnej, 2011;11.

3. Jaroszek M., Respondek W. Nadciśnienie tętnicze. Porady lekarzy i dietetyków. Wyd. Lek. PZWL, Warszawa 2006,44-45.

4. Kara - Perz H., Kosicka T., Głuszek J., Perz S. Nadciśnienie tętnicze utajone - niebezpieczna postać nadciśnienia tętniczego. Kardiologia Oparta na Faktach 2010;4.

5. Januszewicz A., Prejbisz A. Nadciśnienie tętnicze, problemy współczesnej terapii w praktyce klinicznej. Medycyna Praktyczna, Kraków, 2015.

6. Budaj A., Leśniak W. Interna Szczeklika. Medycyna Praktyczna, Kraków 2017.

7. Januszewicz W., Sznajderman M. Jak żyć z nadciśnieniem tętniczym. Wydawnictwo Lekarskie PZWL, Warszawa 2002, 2008.

8. Kaszuba D., Nowicka A. Pielęgniarstwo kardiologiczne. Podręcznik dla studiów medycznych. Wydawnictwo Lekarskie PZWL. Warszawa, 2011.

9. Prejbisz A. Rozpoznanie i leczenie nadciśnienia tętniczego. Drogowskaz dla lekarza. Wydawnictwo Medycyna Praktyczna. Cholerzyn, 2015.

10. Krymska B. Przygotowanie pacjentów $\mathrm{z}$ nadciśnieniem tętniczym do samokontroli i samoopieki. Problemy pielęgniarstwa 2007;15,(2):3. 
11.Więcek A., Nieszporek T. Postępy w nefrologii i nadciśnieniu tętniczym. Medycyna Praktyczna, Kraków 2014.

12. Taran K., Jarosińska E., Kobos J. Nadciśnienie tętnicze - niedoceniany problem edukacji medycznej. Family Medicine \& Primary Care Review 2013;15:3.

Otrzymano: 04.0.2019r.

Zaakceptowano: 21.10.2019r. 
